\title{
Promoting Different Kinds of Learners towards Active Learning in the Web-Based Environment
}

\author{
Anu HAAPALA \\ Department of Education, University of Joensuu \\ P.O. Box 111, FIN-80101 Joensuu, Finland \\ e-mail: anu.haapala@joensuu.fi
}

Received: April 2006

\begin{abstract}
According to many recent studies the effect of learning style on academic performance has been found to be significant and mismatch between teaching and learning styles causes learning failure and frustration. Thus balancing the teaching style and the students' learning style is very important. When emphasizing the individual learning processes, web-based learning offers a good opportunity for differentiating ways of learning. So far the aim of this study is to describe different learners (categorized by cognitive learning styles) and their learning processes in relation to their learning outcomes and perceptions of learning experience on a web-based course. The results of the study showed that there were different kinds of learners, who utilized and experienced the learning material differently. The students varied both in their cognitive learning styles and in their learning processes, but not in the learning results, measured by grades. As an implication, some recommendations were presented for developing the web-based learning environment.
\end{abstract}

Key words: cognitive learning style, web-based learning, active learning, learning from text.

\section{Introduction}

The differences amongst learners have been recognized and perceived in higher education too. According to many recent studies the effect of learning style on academic performance has been found to be significant (e.g., Davidson et al., 1992; Ross and Schulz, 1999; Ross et al., 2001). Thus balancing the teaching style and the students' learning style is very important, because mismatch between teaching and learning styles causes learning failure and frustration, which has implication both for learners and teachers. (Peacock, 2001.) From the pedagogical point of view, considering the principals of effective teaching and learning, the differences between students should be perceived as the starting point for teaching. When emphasizing the individual learning processes, webbased learning offers a good opportunity for differentiating ways of learning.

According to a recent study (Vainionpää, 2006), web-based studying has its own important role in higher education. According Hong (2002), there are three main reasons for this. Firstly, information technology has recently been developed for educational purposes, also widely for higher education. Secondly, education is increasingly embracing active learning models in preference to the traditional transmission. Thirdly, a growing 
demand for continuing education is changing the characteristic structure of the tertiary student population. All in all, information technology and especially web-based learning is one of the most rapidly developing areas in higher education pedagogy, as it has been described in the article of Atjonen and $\mathrm{Li}$ in this journal.

Vainionpää's study (2006) shows that the quality of the learning materials is very important for the studying to be successful. In order to define 'quality' in web-based leaning, studies are needed to find out more explicitly how different students utilize the different pedagogical solutions in the web-based environment and specific web-based courses. The study reported in this paper is one attempt to describe different learners and their learning processes in relation to their learning outcomes and perceptions of learning experience on a web-based course. The aim of this study is to examine the following questions:

- What kinds of learners (categorized by cognitive learning style) are taking part in a web-based course?

- What are the characteristics of different kind of learners in the process of learning and utilizing the learning material?

- Is there any significant difference between different types of learners in exploiting the different learning material or experiencing the usefulness of different learning material in web-based environment on a specific web-based course?

The study reported in this paper is a part of larger research project, which aims to discover how different types of students and learners utilize web-based environment in their learning. The main question is how reasonable pedagogical solutions made by teachers match up to the learning processes and outcomes experienced and perceived by learners.

\section{Differences in Students' Learning Styles}

Learning style is a term widely used for examining and understanding the individual learning differences, and research in the area focuses on examining the different perspectives of how the mind operates. The differences in learning, learning abilities, and learning styles might be explained by Thorndike in terms of the differences in environmental, emotional, personal and biological factors among individuals (Hergenhahn and Olson, 1993).

According to Felder (1993), learning style may be defined in part by the answers to five questions. The first one is what type of information the student preferentially perceives. The second question is through which modality is sensory information most effectively perceived, and the third, with which organization of information is the student most comfortable. Also the questions of how the student prefers to process information and how the student progresses toward understanding are essential in defining the characteristics of the concept "learning style".

In order to answer these questions, there have been plenty of different studies in the field of different learning styles. According to Dunn, Beaudry and Klavas (1989), there are four dimensions to the study of learning styles. The cognitive learning style 
describes information processing habits representing the learner's typical mode of perceiving, thinking, problem solving, remembering, and relating to others, when the affective learning style encompasses aspects of personality (attention, emotion, motivation, incentive, curiosity, boredom, anxiety and frustration). The third dimension is the physiological learning style, which describes the characteristic learning-related behaviours of the human body. These relate to the senses (auditory, visual or kinesthetic) that are used for learning. The fourth dimension is the psychological learning style, which relates to how inner strength and individuality affect the learning of the individual.

Plenty of different classifications and methods concerning the differences in learning styles have been used in the studies. For example the Gregorc Style Delineator is a selfreport tool used to measure cognitive learning styles (thinking and learning processes), while the Myers-Briggs Type Indicator (MBTI) classifies students according to their preferences on scales derived from Jung's theory of psychological types. Kolb's Learning Style Model classifies students as having a preference for 1) concrete experience or abstract conceptualization (how they take information in), and 2) active experimentation or reflective observation (how they internalize information). Honey and Mumford's Learning Style Questionnaire (LSQ) has been proposed as an alternative to Kolb's LSI. The LSQ was developed to report management trainees' learning style preferences and has subsequently been applied to a wide range of subjects, including students in higher education. Herrmann Brain Dominance Instrument (HBDI) classifies students in terms of their relative preferences for thinking in four different modes based on the task-specialized functioning of the physical brain. These examples show that all of these models highlight both the differences and the similarities of the dimensions of learning style.

There are plenty of different concepts and terms closely related to learning style that concern the differences of learning and learning abilities. One of them is learning strategy, which refers to the activities by which learning is achieved. For example, reading aloud, copying notes, consulting peers, and asking the instructor for clarification are all learning strategies. The use of learning strategies allows students to actively process information, thereby influencing their mastery of material and subsequent academic achievement (Pintrich et al., 1993). When considering the relationship between these two concepts, the learning style is the more fundamental base for using different learning strategies.

However, learning style is not constant. According to the prior research (Matthews, 1994), there are, for example, differences in the learning styles utilized by students in different majors. Jones, Reichard and Mokhtari (2003) have reported that there were significant differences in students' learning style preferences across disciplines, but not for gender, when using a modified version of the Kolb Learning Style Inventory IIa. In the same study, the results showed that student learning style preferences varied by academic performance.

It might be said that adjusting learning styles based upon the demands of the students' particular course is one dimension of general academic abilities (Biggs et al., 2001) and this is why it is important to make students aware of their own learning styles. This is the first stage when developing the individual learning styles. For example Nelson et al. (1993) reported that students who received learning style instruction were more likely to 
continue in the university. They also recommended mentors and teachers to develop the students' learning style instrument, develop a background for their individual learning styles, and make them aware of strategies in which to accommodate individual styles.

\section{The Web-Based Environment for Learners of Different Cognitive Learning Styles}

The hypothesis in this study, based on the studies described above, is that there are learners with different cognitive learning styles participating in the course. On the other hand, web-based learning offers a good opportunity for differentiating ways of learning. This was the starting point for developing the web-based course, where different types of learners have an opportunity to choose the material suitable for them.

There are plenty of possibilities to use a web-based environment for educational purposes. Vahtivuori and Masalin (2000) have divided the use of informational technology in web-based learning into instrumental, pedagogical, communal, and communicational environments of use. All these viewpoints might be utilized when designing the web-based environment for a specific course. Despite different views on the use of web-based environments, much of the material students have to use is presented in written form, most commonly in texts and readings. Marton $(1974,1988)$ and Marton and Säljö (1984) are kind of classics in the field of research concerning reading, text learning and processing information, which is why their model of learning approaches is used as the theoretical starting point.

In the model of learning approaches (Marton and Säljö, 1984), learners are divided into four categories based on their levels of processing and learning styles. Since its introduction, this model of learning approaches has been widely used. It has also been a fundamental model for developing new ways of examining the modes, approaches, strategies and styles in learning and instruction. In spite of its limitations, it was also utilized in this study as a framework for the different aspects of cognitive learning styles, when, firstly, developing the material for the web-based course. Secondly, it was used in order to examine the differences in learning processes and approaches, and based on them, possible differences in the learning results and in the utilization of material developed for active learning.

The second theoretical starting point for developing the web-based course involves reading and learning. When talking about learning from written material (text, figures, tables etc.) the main strategy for learning concerns reading. While it is doubtless important, there is evidence that the task of reading to learn is problematic for students in higher education. Reading and remembering information from a text can be one of the most challenging aspects of learning (Maclellan, 1997). There can be a lot of variation as to how texts are used from one course to another, which means that the strategies that are effective for reading and studying text will also vary from course to course. Often students seem to have problems with both the complexity and the amount of the material they have to read. Most studies reported that prior or baseline knowledge and interest exert independent effects on text learning (e.g., Alexander et al., 1994). 
There are always different types of readers taking part in web-based courses. In her study on different readers, Kairavuori (1996) observed that the reading strategies might vary a great deal depending the context, mode, or type of text and personal variables. She concludes that reading without focused attention is not really reading at all. To aim for active reading and effective learning, the reader needs to be a more active partner with the writer in making or creating meaning from the text. Active reading requires interacting with the information, or creating an "internal dialogue" with the text. It is also reading actively, commenting on or asking oneself questions about points in the text and looking for main points and supporting evidence or examples. The principles of active reading and effective learning have been developed actively in the field of science education during the last decades (see, e.g., Baker 1991).

The learning material for the web-based course was revised, firstly, by paying attention to the characteristics of different cognitive learning styles, secondly, based on the principles of active reading and learning (Kairavuori, 1996; Maclellan, 1997), and thirdly, on the basis of both designing instructional and informational text in the webbased environment (Hartley, 2004) and aspects of learning from hypertext (Shapiro and Niederhauser, 2004).

In practice, adapting these ideas to the web-based course meant that the theoretical framework guided the organisation of the course, the revision and structuring of the learning material, and the choice of the teaching methods. Thus, the learning material was structured, and there were tables, figures, and summaries for helping students to create patterns and connections (see Ainsworth, 2003). Active readers know what they are looking for and how to find it, and in order to achieve this, the students were asked at the beginning of the course to write down their personal aims for the course in the electric learning diary and to answer some questions about the meaning of this course. They were also asked to write down some ideas about the course topic (Instructional process analysis) so as to become aware of the level of prior knowledge and to promote them to relate the new knowledge to the old.

In active reading and learning one important strategy is questioning, which is why plenty of questions for consideration were included in the learning material. There were also plenty of neutral and provocative comments and questions included in the text. Active learners were supposed to be also selective readers and to know what not to read. In the web-based environment, the differentiation of levels or themes is easy to realize by using hypertext and links. For those students who tend to retain and understand information best by actively using it, the students were encouraged to question and make notes in the learning diary.

\section{The Procedure of the Study}

There were 58 university students (50 females, 8 males), who had education as their major, in taking the advanced level course in education. The course officially lasted three months, but after the course the students were also allowed to utilize the material for other assignments. 
Before the course, the students were asked to fill in a questionnaire to find out the characteristics of their cognitive learning style. The cognitive learning style subscale contained 30 items. The questionnaire was developed to quantify the cognitive learning styles, adapted and focused for active reading and learning. The questions for identifying the characteristics of cognitive learning style were modified mainly on the basis of the Gregorc Style Delineator (Gregorc, 1982) and the research of both Marton (1974) and Marton and Säljö (1984). For adapting the questions for frame of active reading and learning, the research of Kairavuori (1996) was utilized. At the end of the course the students were asked to fill in the same questionnaire again in order to measure the experienced characteristics of learning styles. There were also some extra questions for measuring some learning experiences after the course.

The students were asked to make writings and assignments for collecting data about their prior knowledge and progress of learning. It is widely understood that knowledge is constructed through the learner's experience of learning. Thus students' prior knowledge is important information both for the teacher when facilitating the course, and for the student him/herself during the course. This is why it is important to support the students to conceptualize their prior knowledge at the beginning of the course. On the other hand, the writing based on the students' prior knowledge was used as a base document for assessing the progress of learning after the course. Therefore the students were also asked to write an essay to find out the level of their prior/ baseline knowledge. The essays were classified into three groups (novice, average and experts). Similarly, the students were analyzed at the end of the course when they wrote the essay again. The grade was also used as an indicator of the learning progress.

Learning diaries and course logs were used for examining the students' learning process. The learning diary was included in the web-based course, because self-explanation is an effective meta-cognitive strategy that can help learners develop deeper understanding of the study material and promote them towards active reading and learning. The students were asked to include both their own notes to consider their learning (comments, abstracts, questions etc.) and to fulfil some other tasks. Thus the diary functioned as a learning log, through which the teacher could examine some guidelines for the learning process of each student. There were also some numeric data in the course log (amount of access to the course, timing etc.) that was found useful in examining the learning process and practices of each student.

\section{Different Types of Learners Utilizing the Principles for Active Learning}

To answer the first research question, what kinds of learners (categorized by cognitive learning style) are taking part in the web-based course, the data was described using some descriptive parameters and analysed using K-means cluster analysis.

As a result of the K-means cluster analysis, the students were divided into four different groups according to their cognitive learning styles. Using the categories labelled by Marton and Säljö (1984) and Kairavuori (1996), there were 24 students who had characteristics of "horizontalizing", 23 students having characteristics of "active reflectors", 
three students having characteristics of "technification" and four students who had some characteristics of "hyperintending". Four students could not be categorized into any of these groups. There were one to four typical characteristics in every group, and after the cluster analysis, Spearman's rho was used for specifying how the different types of learners experienced and used supportive learning material.

The students varied both in their learning processes and in their learning approaches, but not in the learning result measured by grades. According to the descriptive statistics, the mean grade was $2.27(1-3)$, while the standard deviation was 0.37 . Thus the great majority of the students reached the course aims very well, in spite of differences in learning approaches and processes. Use of the web-based environment and material was one indicator when examining the learning process. The students seemed to vary a great deal in using the web-based environment, the highest amount of access for the course area being 631 and the lowest only 50. An average student visited the course area 254 times (std. deviation 123) and the average visit lasted 22 minutes. There were no statistically significant differences in the use of the course area between the different types of learners. The other course log indicator used for the study purposes was the use of conversation. An average student wrote 108 comments (std. deviation 71), but there were some students who seemed not to utilize the conversation area at all (only 3 accesses). The majority of the students did use the conversation area (mode 196) every time they visited the webbased environment. The content of conversation was also analyzed, but there were no statistically significant differences between different types of learners.

For answering the question, what are the characteristics of different kinds of learners at the process of learning and utilizing the learning material, the types of learners were examined group by group. Each group was analyzed based on both quantitative (questionnaire filled in before and after the course, course log) and qualitative data (learning diaries, essays). The statistically significant (Spearman's rho; $p<.001$ ) results of the quantitative analysis and the relevant results of the qualitative analysis were reported as follows.

The learners of "horizontalizing" preferred studying step by step, concentrated on remembering the facts, and they seemed to use lists, keywords, etc. to remember the facts. There were also plenty of statistically significant $(p<.001)$ correlations between these three characteristics and the statements concerning supportive learning material used and experienced. The "horizontal" learners preferred clearly structured material $(r=.42)$ and both clear instructions and exact criteria for assessment $(r=.35)$. They were the only group who felt that mistakes were disturbing $(r=.33)$. They concentrated on remembering the facts, but they took no notes (lists, mind maps etc.) $(r=.40)$. Yet they tried to give examples themselves $(r=.52)$ and preferred examples included in the learning material $(r=.36)$. In spite of their systematic approach to learning, the learners of "horizontalizing" also tried to combine the new information with ther prior knowledge $(r=.38)$ and tried to figure out the course as a whole $(r=.36)$.

There were four learners on the course who were categorized into the group of "hyperintending". Because of the small number, the results of the statistical analysis were indicative only, and the final results were based more on the learning diaries and findings 
from the course log. The "hyperintending" learner felt that examples made him learn and he used mnemonics. He liked to pass the course quickly and preferred clear instructions and exact criteria for assessment.

The learners of "technification" were a group of three students. When analysing their individual processes of learning, some common features were found. The learners of "technification" tried to figure out the course as a whole and they perceived that they tried to combine the new information with the prior knowledge. When they were learning something complicated, they also tried to conceive the whole before learning the details. When trying to memorise facts, they used lists, keywords, mnemonics, etc. They also made some notes in the learning diary. They seemed to distinguish the relevant subject matter easily and utilized links and hypertexts.

The fourth group of learners was labelled as "active reflectors". It included 23 students who mainly had characteristics different from those of the students in the other three groups. The active reflectors seemed to be aware of trying to combine the new information with the prior knowledge; they tried to set the individual course as a part of the degree. They were questioning themselves when studying and they seemed to distinguish the relevant subject matter easily. There were also plenty of statistically significant $(p<.001)$ correlations between these four characteristics and the statements concerning supportive learning material used and experienced.

When the "active reflectors" seemed to be aware of trying to combine the new information with the prior knowledge, they tried to conceive the course as a whole $(r=.56)$, and in general when learning some complicated, they tried to figure out the whole before learning the facts $(r=.59)$. They also liked to have feedback during the course $(r=.41)$. When the "active reflectors" tried to set the individual course as a part of the degree, they too liked to have clear instructions and exact criteria for assessment $(r=.46)$. If they were questioning themselves when studying, they also agreed that they had developed their own learning strategies $(r=.35)$. It was also statistically significant that when the "active reflectors" easily distinguished the relevant subject matter, they also preferred flexible learning material $(r=.37)$ and took notes (mind maps etc.) $(r=.35)$.

Differentiating is relevant in developing web-based environments if it is assumed that the characteristics of different types of learners explain any elements in learning process or result. This study was concerned with whether there is any significant difference between different types of learners in exploiting the different learning material or experiencing the usefulness of different learning material in web-based environment in specific web-based course. To answer this question, different types of learners and some variables of their learning process and studying were analyzed by using the Kruskal-Wallis test.

According to the results of the test, different learners did not differ from each other in their activeness in using the course area. Neither were such differences found in the learning results measured by grade, in attitudes towards learning in web-based environments, in experiencing advantages of using learning diaries, or in motivation $(p<.05)$. However, different types of learners differed from each other by being aware of what kind of learners they are, and by attempting to develop their learning strategies during the course. The different types of learners also differed in benefiting from the comments, questions, 
etc. included in the texts, in utilizing the hypertext and links included in learning material in different ways, and in investing their time in learning $(p<.05)$.

\section{Conclusion}

There were different kinds of learners in the web-based course and many differences became evident in experiencing and utilizing the supportive learning material. Thus the main result is similar to previous studies (see Karuppan, 2001) in spite of the different definition and theoretical background of learning style.

As also shown in previous studies (Kearsley, 2000), learning styles did not affect the students' achievements in the course. There were no differences in the learning results measured by grade nor in the progress in their learning measured by essays; in spite of differences in learning styles and learning processes, diversified web-based material had been utilized in a suitable way by each learner. Thus, the need for differentiating is obvious, and the web-based environment offers a base for developing flexible, multi-level and differentiated learning material. It has also been shown in previous studies (e.g., Aragon et al., 2002) that students can learn equally well in either delivery format, regardless of their learning style, provided that the course is developed around an adult learning theory and sound instructional design guidelines.

Choosing the right material might also be a major challenge for the student who is uncertain of his/her learning style or learning aims. Thus it might be important to support students in developing their abilities to be aware of their learning approaches, styles and strategies. The teacher is also required to be aware of different kinds of learners and to have the time, recourses and abilities to develop a web-based environment suitable for them. Based on they results of the influence of cognitive learning styles on performance, Ross, Drysdale and Schulz (2001) recommended highly that students complete a learning style instrument early in the course. It might be recommended also based on the results of this study.

According to the results, the learners of "horizontalizing" wish to have clear instructions and material for studying and learning. In their learning process, they take advantage of examples, clear figures, tables and lists and promoting material from which to make examples themselves for understanding theories in practice. When developing the webbased environment for them, the optional learning material should be clearly structured and explained. On the other hand, the supportive questions for them should be rather in the form of making them figure out the whole rather than emphasizing the facts.

The learners of "hyperintending" might utilize the same kind of web-based environment - the only differing characteristic being that they wish to pass the course quickly. Thus it might be asked, whether they are interested in learning at all, or only in gaining credits. Both the learners of "horizontalizing" and "hyperintending" do not want to use learning diaries or extra material during their learning process. All in all, they might benefit from the web-based environment, where the course is well structured and divided into periods and sections. The learners of "horizontalizing" and "hyperintending" are obviously more concrete than the other groups of learners. According to Gregorc (1982), 
abstract learners have more of an affinity for computer applications than concrete students. Thus they might be encouraged to use web-based environments before focusing on learning.

The learners of "technification" are more holistic learners and try to handle different questions from the holistic point of view. At the beginning of the course they make themselves familiar with the course aims and material by reading the outline of the course and by glancing through the learning material. They like to have summaries. In spite of the holistic point of view in learning, they make specified notes and also concentrate on remembering the facts. They use the electronic learning diary especially for taking specific notes. Because they have a view of what to learn and why, they are able to choose the material essential just for them, and web-based environments suit them well.

The active reflector is also a kind of holistic learner and who uses holistic noting techniques unlike the learners of "technification". The active reflectors use mind maps and various drawings (figures made by themselves) to reach the learning aims. In webbased environments they need a way to express themselves and they use both electronic learning diaries and the conversation area. Comparing the active reflectors to Gregorc's categorization (1982), they are likely to equal the Abstract Random, who requires environments that are flexible, intuitive, and abound with opportunities for multidimensional thinking. They do not need the supportive questions that much, but they ask rather a lot of questions themselves and try to find out the answers from the differing sources of material.

Web-based environments seem to be highly suitable for active reflectors, because they are able to utilize different learning materials and are not confused about the wide range of instructions for the assignment. Obviously, knowing what kind of learners they are, they are in some way in control of the learning process. In this context the role of the teacher is rather that of an instructor than a teacher, but this kind of learners still want to have contact with the teacher to ask questions rather about the content of the course than of its organization. Thus they use the conversation area, the learning diary and email for contacting. They use the criteria of assessment at the beginning of the course to figure out the learning aims and as a framework for the course. When developing the web-based environment for active reflectors, it is important at the beginning of the course to give them an opportunity for scanning all the material even though it is divided into sections.

There were only 58 students taking part in this study, with only a few students in two of the groups and four students who could not be categorized into any of the groups. Because of the shortage of different kinds of learners in each group, the correlations are not absolutely correct estimates. In spite of this, the results might give some indication for teachers who are developing web-based courses and environments in which information technology will be utilized. Because the study reported in this paper is a part of larger research project, the aim is to strengthen and make the indicative results more reliable in the next phases of the project. An interesting question might also be, whether there is a relationship between perceptions of different pedagogical solutions and different cognitive learning styles, or whether there are other explanatory factors.

Developing a good web-based environment is very challenging. There are always different kinds of learners taking part in the course and preparing supportive material 
for all of them requires a lot of time, resources and an awareness of varying pedagogical solutions and materials. If there is too much differentiation in the course, it is bad for some and good for others, but if there is only one kind of material and solutions, someone will always suffer. There are always different sorts of teachers, materials and aims in different courses. Maybe the solution is to encourage students to be more aware of their learning strategies, styles and approaches. Thus they might be able to take advantage of each course in a way best suited for them.

\section{References}

Ainsworth, S. (2003). The effects of self-explaining when learning with text or diagrams. Cognitive Science, 27(4), 669-672.

Alexander, P.A., J.M. Kulikowich and S.K. Schulze (1994). The influence of topic knowledge, domain knowledge, and interest on the comprehension of scientific exposition. Learning and Individual Differences, 6(4), 379-397.

Aragon, S.R., S.D. Johnson and N. Shaik (2002). The influence of learning style preferences on student success in online versus face-to-face environments. American Journal of Distance Education, 16(4), 227-245.

Baker, L. (1991). Metacognition, reading and science education. In C.M. Santa and D.E. Alvermann (Eds.), Science Learning: Processes and Applications. International reading association, Newark.

Biggs, J., D. Kember and D.Y.P. Leung (2001). The revised two-factor study process questionnaire: R-SPQ-2F. British Journal of Educational Psychology, 71(1), 133-149.

Davidson, G., W. Savenye and K. Orr (1992). How do learning styles relate to performance in a computer application course? Journal of Research on Computing in Education, 24(3), 349-358.

Dunn, R., J. Beaudry and A. Klavas (1989). Survey of research on learning styles. Educational Leadership, 46(6), 50-58.

Felder, R.M. (1993). Reaching the second tier: learning and teaching styles in college science education. Journal of College Science Teaching, 23(5), 286-290.

Gregorc, A.F. (1982). An Adult's Guide to Style. Gabriel Systems, Maynard, Mass.

Hartley, J. (2004). Designing instructional and informational text. In D. Jonassen (Ed.), Handbook of Research on Educational Communications and Technology. Lawrence Erlbaum associates, Mahwah, New Jersey, London, pp. 917-947.

Hergenhahn, B.R., and M. Olson (1993). An Introduction to Theories of Learning. Prentice Hall, Englewood Cliffs, NJ.

Hong, K.-S. (2002). Relationships between students' and instructional variables with satisfaction and learning from a web-based course. Internet and Higher Education, 5(3), 267-281.

Jones, C., C. Reichard and K. Mokhtari (2003). Are students' learning styles discipline specific? Community College Journal of Research \& Practice, 27(5), 363-376.

Kairavuori, S. (1996). Hauki on kala - Asiatekstistä oppiminen peruskoulun seitsemännellä luokalla (in Finnish, Awareness of learning strategy in factual text learning in school). Helsingin yliopiston opettajankoulutuslaitos, tutkimuksia 166. Hakapaino, Helsinki.

Karuppan, C.M. (2001). Web-based teaching materials: a users' profile. Internet Research: Electronic Networking Applications and Policy, 11(2), 138-148.

Kearsley, G. (2000). Online Education: Learning and Teaching in Cyberspace. Wadsworth, Belmont, CA.

Maclellan, E. (1997). Reading to learn. Studies in Higher Education, 22(3), 277-289.

Marton, F. (1974). Inlärning och Studiefärdighet (in Finnish, Learning and Study Skill). Rapporter från Pedagogiska Institutionen nr 121. Göteborgs universitet.

Marton, F. (1988). Describing and improving learning. In R. Schmeck (Ed.), Learning Strategies and Learning Styles. Plenum Press, New York, pp. 53-82.

Marton, F., and R. Säljö (1984). Approaches to learning. In F. Marton, D. Hounsell and N. Entwistle (Eds.), The Experience of Learning. Scottish Academic Press, Edinburgh, pp. 36-55.

Matthews, D.B. (1994). An investigation of students' learning styles in various disciplines in colleges and universities. Journal of Humanistic Education \& Development, 33(2), 65-75. 
Nelson, B., R. Dunn, S. Griggs, L. Primavera, M. Fitzpatrick, Z. Bacilious and R. Miller (1993). Effects of learning style intervention on college students' retention and achievement. Journal of College Student Development, 34(5), 364-369.

Peacock, M. (2001). Match or Mismatch? Learning styles and teaching styles in EFL. International Journal of Applied Linguistics, 11(1), 1-20.

Pintrich, P.R., D. Smith, T. Garcia and W. McKeachie (1993). Reliability and predictive validity of the motivated strategies for learning questionnaire. Educational and Psychological Measurement, 53, 801-811.

Ross, J., M. Drysdale and R. Schulz (2001). Cognitive learning styles and academic performance in two postsecondary computer application courses. Journal of Research on Computing in Education, 33(4), 400-413.

Ross, J., and R. Schulz (1999). Can computer-aided instruction accommodate all learners equally? British Journal of Educational Technology, 31(1), 5-24.

Shapiro, A., and D. Niederhauser (2004). Learning from hypertext: research issues and findings. In D. Jonassen (Ed.), Handbook of Research on Educational Communications and Technology. Lawrence Erlbaum associates, Mahwah, New Jersey, London, pp. 605-620.

Vahtivuori, S., and T. Masalin (2000). Designing communal web-based learning environments: case GLOBEProject. In S. Tella (Ed.), Media, Mediation, Time and Communication. Emphases in Network-Based Media Education. Media education publications 9. Media education centre, Department of Teacher education, University of Helsinki. http://www.edu.helsinki.fi/media/mep9/vahtivuori_masalin_mep9.pdf

Vainionpää, J. (2006). Erilaiset oppijat ja oppimateriaalit verkko-opiskelussa (in Finnish, Different Kinds of Learners and Learning Materials in Web-based Studying). Acta Universitatis Tamperensis, 1133, Tampereen yliopisto, Tampere.

A. Haapala received her PhD in 2000 (Young People Visions about the Future and Futures Education). He is senior research assistant in educational methodology since 1999 (Faculty of Education, University of Joensuu) and lecturer in adult education (Open University) since 2006 (Faculty of Education, University of Joensuu). He is project manager in the project of Finnish Virtual University (Virtual Study Councelling - OVI) in Educational Technology Centre, University of Joensuu 2001-2003. Her research interests include the questions of learning and instructions in ICT, issues of futures education and some methodological inquiries about the mental representations of learning.

\section{Skirtingu tipu besimokančiuju skatinimas aktyviai naudotis žiniatinklinėmis mokymosi aplinkomis}

\section{Anu HAAPALA}

Pagal daugeli naujausių tyrimų mokymosi stiliaus poveikis akademinei veiklai turi ypatingos reikšmės, mokymo ir mokymosi stiliai dažnai pakankamai skiriasi ir lemia mokymosi nesėkmes bei sukelia frustraciją. Todèl mokymo stiliaus ir studentų mokymosi stiliaus balansas yra nepaprastai svarbus. Tais atvejais, kai svarbus individualaus mokymosi procesas, ypatingas dèmesys turi būti kreiptinas i žiniatinkliu pagrịstą mokymąsi, leidžianti pasitelkti skirtingus mokymosi būdus. Pateikto tyrimo tikslas - aprašyti besimokančiuju (kurie skirstomi pagal kognityvinio mokymosi stilius) ir ju mokymosi proceso skirtumus, atsižvelgiant ị studentu mokymosi rezultatus ir patirtị, igytą naudojantis žiniatinkliu pagrịstu kursu. Šio tyrimo rezultatai parodo, kad esama skirtingu besimokančiuju tipu, skirtingai naudojančiu ir suvokiančiu pateiktą mokomają medžiagą. Nors įvertinti pažymiais besimokančiujų rezultatai beveik nesiskyrė, tačiau jų kognityvieji mokymosi stiliai ir mokymosi procesas buvo gana įvairūs. Straipsnio pabaigoje pateikiamos rekomendacijos, skirtos paskatinti žiniatinklinių mokymosi aplinkų plètrą. 